\title{
Penerapan Komparasi Teorema Bayes dengan Euclidean Probability dalam Pendiagnosaan Dermatic Bacterial
}

\author{
Puji Sari Ramadhan \\ STMIK Triguna Dharma, Jl. AH Nasution, Medan, 20142
}

\begin{tabular}{l} 
KEYWORDS \\
\hline Sistem Pakar, Perbandingan Metode, Euclidean \\
$\begin{array}{l}\text { Probablity, Teorema Bayes, Dermatic } \\
\text { Bacterial }\end{array}$
\end{tabular}

\section{CORRESPONDENCE}

Phone: +62 811-633-2227

E-mail: pujisariramadhan@gmail.com

\section{INTRODUCTION}

Dermatic Bacterial merupakan jenis penyakit kulit yang sering dijumpai pada anak atau balit sebagai penderitanya, hal ini dikarenakan sistem imun yang terdapat pada anak tidak mampu menahan serangan bakteri. Dermatic Bacterial muncul akibat dari sebaran bakteri yang bersumber dari lingkungan yang tidak steril atau kurang bersih[1].

Penanganan yang kurang cepat terhadap penyakit ini juga dapat mengakibatkan kerusakan sel pada kulit serta resiko infeksi kronis pada kulit. Salah satu faktor terhambatnya penanganan terhadap penyakit ini adalah sulitnya melakukan pendeteksian atau pendiagnosaan dini terhadap pasien yang menderita Dermatic Bacterial, hal ini disebabkan masih minimnya pengetahuan serta keterbatasan informasi masyarakat tentang gejala-gejala Dermatic Bacterial dan kurangnya ketersediaan para ahli yang ada diberbagai tempat atau wilayah. Untuk itu perlu membangun sebuah sistem yang memiliki kemampuan dalam memprediksi hasil diagnosa menggunakan konsep Sistem Pakar.
Sistem Pakar merupakan konsep keilmuan yang telah sering digunakan dalam hal menghasilkan kesimpulan diagnosa yang akurat[2]. Kemudian dalam [3] Sistem Pakar dijelaskan untuk dipergunakan dalam menghasilkan kesimpulan, selain itu pada[4] memamparkan Sistem Pakar atau ES adalah bidang ilmu yang mampu melakukan prediksi dan analisis terhadap masalah ketidakpastian atau kemungkinan. Penggunaan konsep Sistem Pakar telah banyak dipergunakan dalam beberapa kasus seperti pendiagnosaan dibidang medis [5] untuk penyakit gigi, [6] kanker, [7] rematik philogimia, [8] engkel persendiaan, [9] demam berdarah, [10] Impetigo, [11] Xlindked Aggmalomunia, dan [12] penyakit kulit. Dengan adanya penggunaan Sistem Pakar dalam beberapa kasus tersebut maka dapat diyakini bahwa Sistem Pakar telah teruji dalam melakukan analisis prediksi untuk menghasilkan kesimpulan.

Pada penelitian ini, dalam menyelesaikan kasus pendiagnosaan terhadap penyakit Dermatic Bacterial akan menggunakan analisis pengkomparasian metode yang ada dalam Sistem Pakar yaitu Teorema Bayes dengan Euclidean Probability, yang bertujuan untuk mengetahui metode yang paling baik dan akurat dalam melakukan pendiagnosaan tehadap penyakit Dermatic Bacterial sehingga nantinya akan diterapkan kedalam aplikasi layanan diagnosa. 
Pemilihan metode Teorema Bayes dan Euclidean Probability, didasari dengan banyaknya dan seringnya penerapan metode tersebut digunakan dalam kasus dan penelitian sebelumnya, seperti penggunaan Teorema Bayes dalam melakukan pendiagnosaan terhadap kasus [13] dermatis imun, kemudian [14] penyakit elfrosen, dan [15] untuk varicella simplex, selain itu terdapat juga penerapan Euclidean Probability dalam beberapa kasus, seperti pada[16] pendeteksian Granomatolus, kemudian [17] inflamasi imun, [18] kanker rahim, tidak hanya dalam dunia kesehatan, metode tersebut juga digunakan dalam bidang lain seperti [19] untuk mengidentifkasi jaringan dan kerusakan perangkat[20].

Dalam penelitian ini konsep yang digunakan dalam menyelesaikan kasus diagnosis Dermatic Infektivirus akan menggunakan penerapan metode Euclidean Probability dan Teorema Bayes. Hal ini diawali dengan pengumpulan pengetahuan tentang penyakit Dermatic Infektivirus kemudian melakukan penelusuran gejala mengggunakan Forward Chaining selanjutnya akan dilakukan penerapan metode Euclidean Probability dan Teorema Bayes. Penggunaan kedua metode tersebut dilakukan untuk dapat mengetahui metode yang paling baik digunakan dalam mendiagnosis Dermatic Bacterial dengan cara membandingkan nilai akurasi diagnosis yang dihasilkan kedua metode tersebut.

Selain itu untuk mengoptimalkan pengujian dalam membandingkan Euclidean Probability dengan Teorema Bayes, maka akan menggunakan teknik eksponensial dalam menghitung nilai diagnosis yang dihasilkan sehingga dapat diketahui metode yang paling baik digunakan untuk diagnosis Dermatic Bacterial.

Dengan adanya aplikasi layanan diagnosa ini nantinya akan dapat memberikan kemanfaatan bagi masyarakat dalam melakukan pendiagnosaan Dermatic Bacterial yang dapat dijadikan sebagai diagnosa awal sehingga dapat segara melakukan penanganan dini terhadap pasien yang kemungkinan menderita Dermatic Bacterial.

\section{METHOD}

Dalam melakukan penelitian ini, perlu menyusun kerangka kerja yang berisi tentang tahapan atau langkah-langkah dalam menyelesaikan permasalahan tentang analisis komparasi metode Teorema Bayes dengan Euclidean Probability untuk pendiagnosaan penyakit Dermatic Bacterial, berikut kerangka kerja penelitian yang telah disusun.

\section{Pengumpulan Pengetahuan}

Langkah awal yang akan dilakukan dalam menyelesaikan penelitian ini adalah dengan mengumpulkan pengetahuan serta informasi terkait Dermatic Bacterial yang diperoleh dari pakar kesehatan kulit.

\section{Pelacakan Forward Chaining}

Dalam penyelesaian kasus ini akan menerapkan konsep penelusuran dengan teknik runut maju atau sering dikenal dengan Forward Chaining. Dalam [21] menjelaskan bahwa Forward Chaining didefinisikan sebagai suatu teknik penelusuran yang cara kerjanya melakukan pelacakan kondisi dengan runut maju untuk menghasilkan kesimpulan dari kondisi yang adaPada [22] menjeleaskan bahwa pelacakan maju merupakan teknik yang digunakan melalui konsep sebab akibat. Penggunaan Forward Chaining telah banyak digunakan dalam beberapa kasus seperti pada[23], [24] dan [25].

\section{Proses Teorema Bayes}

Setelah melakukan pelacakan terhadap gejala yang terdapat pada penyakit Dermatic Bacterial maka langkah selanjutnya adalah menerapkan metode Teorema Bayes untuk dapat mengetahui nilai probabilitas atau kemungkinan pasien menderita Dermatic Bacterial. Metode ini merupakan salah satu metode yang dapat menghasilkan nilai probabilitas hipotesa dari sebab-sebab yang terjadi[15].

Pada [13] mengemukakan bahwa Teorema Bayes merupakan metode yang mengabungkan aturan dengan nilai probabilitas atau bayes dalam menghasilkan kesimpulan berdasarkan permasalahan yang terjadi. Berikut tahapan dari penerapan Teorema Bayes :

1. Menghitung nilai bobot gejala

$$
P(H)=\frac{P(H 1)}{\sum_{k=1}^{1}}
$$

2. Menghitung nilai semesta tanpa melihat dari evidence

$$
\sum_{k=1}^{n}=P(H i) * P\left(E \mid H i_{-} n\right)
$$

3. Menghitung nilai probabilitas dengan nilai dari evidence yang berpengaruh.

$$
P(H i)=\frac{P(E \mid H i) * P(H i)}{\sum_{k=1}^{n} P(E \mid H i) * P(H i)}
$$

4. Menghitung nilai hipotesa dari total bayes

$$
\sum_{k=1}^{n} \text { Bayes }=\text { Bayes } 1+\text { Bayes }_{2}+\ldots+\text { Bayes }_{n}
$$

\section{Proses Euclidean Probability}

Tahapan selanjutnya adalah menerapkan Euclidean Probability dalam menghitung nilai kepastian atau kemungkinan terhadap kasus Dermatic Bacterial berdasarkan gejala yang diderita.

Dalam [10] menjelaskan bahwa Euclidean Probability merupakan sebuah metode yang memiliki kemampuan dalam menghasilkan nilai kemungkinan dari permasalahan yang kompleks berdasarkan kondisi yang terjadi Berikut bentuk persamaan Euclidean Probability:

$$
E P=\sqrt{\begin{array}{l}
\left(E_{1} \times N B E_{1}\right)^{2}+\left(E_{2} \times N B E_{2}\right)^{2} \\
+\ldots+\left(E_{n} \times N B E_{n}\right)^{2}
\end{array}}
$$

\section{Komparasi Metode}

Pada bagian ini akan dilakukan perbandingan metode Teorema Bayes dengan Euclidean Probability melalui analisis perbandingan nilai akurasi diagnosa dan juga melakukan analisis eksponensial yang merupakan teknik matematika yang 
digunakan untuk menggambarkan nilai prioritas terhadap beberapa opsi pemilihan yang ada.

\section{Impelementasi Sistem}

Dalam fase ini akan dilakukan pengimplementasian sistem layanan diagnosa dengan menerapkan metode yang telah teruji dengan nilai akurasi terbaik.

\section{RESULTS AND DISCUSSION}

Pada pembahasan ini akan mengemukakan tentang cara kerja atau langkah-langkah yang akan dilakukan berdasarkan kerangka kerja yang telah disusun untuk menyelesaikan permasalahan perbandingan Euclidean Probability dan Teorema Bayes untuk mendiagnosis Dermatic Bacterial menggunakan komparasi nilai akurasi dan teknik eksponensial.

\section{Data Pengetahuan}

Hasil yang diperoleh dari pengumpulan data kepakaran berupa data pengetahuan dan informasi tentang daftar gejala, penyakit serta nilai bobot probabilitas gejala yang diperoleh dari Dr. Rudidjas, Sp.A(K) selaku pakar kesehatan anak yang dapat disajikan sebagai berikut.

Tabel 1. Data Pengetahuan

\begin{tabular}{|c|c|c|c|c|}
\hline \multirow[b]{2}{*}{ Kode } & \multirow[b]{2}{*}{ Nama Gejala } & \multicolumn{3}{|c|}{ Jenis Dermatic Bacterial } \\
\hline & & $\begin{array}{c}\text { Impetig } \\
o\end{array}$ & Frunkel & Leprosy \\
\hline G1 & Pembengkakan & 0.4 & 0.2 & 0.2 \\
\hline G2 & Demam & 0.6 & & \\
\hline G3 & $\begin{array}{lr}\text { Nyeri } & \text { bagian } \\
\text { kulit } & \text { yang } \\
\text { bengkak } & \end{array}$ & 0.4 & & \\
\hline G4 & $\begin{array}{ll}\text { Bintik putih } \\
\text { terbentuk } \\
\text { benjolan }\end{array}$ & 0.2 & & \\
\hline G5 & Melepuh & 0.4 & & \\
\hline G6 & Kaku & & 0.4 & \\
\hline G7 & Gatal & & 0.6 & \\
\hline G8 & Kulit memerah & & 0.4 & \\
\hline G9 & $\begin{array}{ll}\text { Berair dan } \\
\text { Nanah }\end{array}$ & & 0.2 & 0.2 \\
\hline G10 & Bersisik & & & 0.6 \\
\hline G11 & Terasa panas & & & 0.4 \\
\hline G12 & $\begin{array}{l}\text { Peradangan } \\
\text { kulit }\end{array}$ & & & 0.2 \\
\hline G13 & Lemas & & & 0.6 \\
\hline
\end{tabular}

Setelah melakukan pengumpulan data pengetahuan maka selanjutnya dapat dibentuk tiga buah rule atau aturan, yaitu sebagai berikut :

Rule-1 : IF Pembengkakan And Demam And Nyeri bagian kulit yang bengkak And Bintik putih terbentuk pada benjolan And Melepuh THEN penyakit = Impetigo

Rule-2 : IF Pembengkakan And Kaku And Gatal And Kulit Memerah And Berair/Nanah THEN penyakit $=$ Frunkel
Rule-3 : IF Pembengkakan And Berair/Nanah And Bersisik And Terasa Panas And Peradangan kulit And Lemas THEN penyakit $=$ Leprosy.

Berdasarkan data aturan yang telah terbentuk maka dapat dilakukan proses pelacakan atau penelusuran dengan Forward Chaining.

\section{Penerapan Forward Chaining}

Pada tahapan ini, akan dilakukan proses penelusuran terhadap pasien yang mengalami gejala-gejala yang diindikasikan mengalami Dermatic Bacterial menggunakan Forward Chaining. Sebagai contoh kasus, terdapat seseorang mengalami gejala-gejala seperti : pembengkakan, demam dan bintik putih pada kulit. Berdasarkan data kasus tersebut maka dapat diperoleh tiga rule yang terkait, berikut proses penelusuran Forward Chaining :

Rule-1 : IF Pembengkakan And Demam And Bintik putih terbentuk pada benjolan $T H E N$ penyakit = Impetigo

Rule-2 : IF Pembengkakan THEN penyakit $=$ Frunkel

Rule-3 : IF Pembengkakan THEN penyakit = Leprosy

Dari proses penelusuran yang dilakukan, maka diketahui bahwa seseorang pada kasus tersebut kemungkinan menderita jenis penyakit Impetigo, Frunkel dan Leprosy. Sehingga perlu menggunakan perhitungan metode Teorema Bayes dan Euclidean Probability untuk mengetahui nilai probabilitas diagnosa yang paling besar diantara ketiga jenis penyakit tersebut.

\section{Penerapan Teorema Bayes}

Dari data kasus yang diangkat, maka dapat dilakukan proses perhitungan Teorema Bayes dengan langkah-langkah sebagai berikut.

1. Menghitung nilai bobot gejala yang dialami

Jenis penyakit Impetigo :

Pembengkakan $=0.4$

Demam $\quad=0.6$

Bintik putih $\quad=0.2$

Total bobot gejala $=0.4+0.6+0.2=1.2$

Jenis penyakit Frunkel :

Pembengkakan $=0.2$

Jenis penyakit Leprosy :

Pembengkakan $\quad=0.2$

2. Menghitung nilai semesta tanpa melihat dari evidence

Jenis penyakit Impetigo :

$\mathrm{P}(\mathrm{H} 1)=0.4 / 1.2=0.33$

$\mathrm{P}(\mathrm{H} 2)=0.6 / 1.2=0.50$

$\mathrm{P}(\mathrm{H} 3)=0.2 / 1.2=0.17$

$\mathrm{P}(\mathrm{Hi}) \times \mathrm{P}(\mathrm{E} \mid \mathrm{Hi})=(0.4 \times 0.33)+(0.6 \times 0.50)+(0.2 \times 0.17)$ $=0.47$

Jenis penyakit Frunkel :

$\mathrm{P}(\mathrm{H} 1)=0.2 / 0.2=1$

$\mathrm{P}(\mathrm{Hi}) \times \mathrm{P}(\mathrm{E} \mid \mathrm{Hi})=(0.2 \times 1)=0.2$ 
Jenis penyakit Leprosy :

$\mathrm{P}(\mathrm{H} 1)=0.2 / 0.2=1$

$\mathrm{P}(\mathrm{Hi}) \times \mathrm{P}(\mathrm{E} \mid \mathrm{Hi})=(0.2 \times 1)=0.2$

3. Menghitung nilai probabilitas dengan nilai dari evidence yang berpengaruh

Jenis penyakit Impetigo :

$\mathrm{P}(\mathrm{H} 1 \mid \mathrm{E})=(0.4 \times 0.33) / 0.47=0.29$
$\mathrm{P}(\mathrm{H} 2 \mid \mathrm{E})=(0.6 \times 0.50) / 0.47=0.64$
$\mathrm{P}(\mathrm{H} 3 \mid \mathrm{E})=(0.2 \times 0.17) / 0.47=0.07$

Jenis penyakit Frunkel :

$\mathrm{P}(\mathrm{H} 1)=(0.2 \times 1) / 0.2=0.2$

Jenis penyakit Leprosy :

$\mathrm{P}(\mathrm{H} 1)=(0.2 \times 1) / 0.2=0.2$

3. Menghitung nilai hipotesa bayes

Jenis penyakit Impetigo :

$\sum$ Bayes $=(0.4 \times 0.29)+(0.6 \times 0.64)+(0.2 \times 0.07)$

$=0.51$

Jenis penyakit Frunkel :

$\sum$ Bayes $=0.2 \times 0.2$

$=0.04$

Jenis penyakit Leprosy :

$\sum$ Bayes $=0.2 \times 0.2$

$=0.04$

$\operatorname{Max}(0.51,0.04,0.04)=0.51$

Berdasarkan perhitungan yang telah dilakukan dengan Teorema Bayes maka diperoleh kesimpulan pada kasus tersebut terdiagnosa jenis penyakit Impetigo dengan nilai kepastian 0.51 atau dengan persentase $51 \%$.

\section{Penerapan Euclidean Probability}

Pada tahapan ini, akan dilakukan proses perhitungan nilai diagnosis penyakit dengan menggunakan Euclidean Probability. Berikut perhitungan Euclidean Probability dari contoh kasus yang telah dilakukan penelusuran:

1. Menentukan nilai bobot kondisi

Nilai kondisi diperoleh dari keterangan gejala yang dialami [4], data nilai bobot kondisi dapat terlihat pada Tabel 2.

Tabel 2. Nilai kondisi

\begin{tabular}{ccc}
\hline No & Kondisi & Nilai \\
\hline 1 & Ya & 1 \\
2 & Tidak & 0 \\
\hline
\end{tabular}

2. Menghitung nilai Euclidean

Perhitungan Euclidean Probability akan dilakukan untuk masing-masing jenis penyakit dari data kasus tersebut :

Jenis penyakit Impetigo:

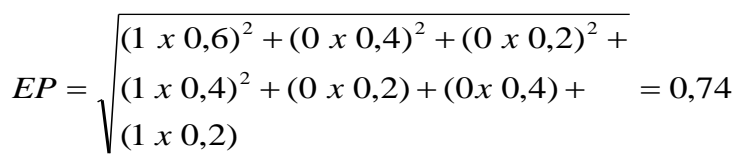

Jenis penyakit Frunkel:

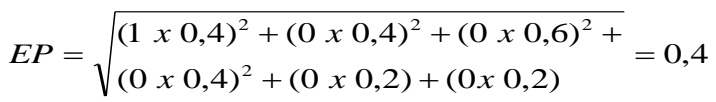

Jenis penyakit Leprosy:

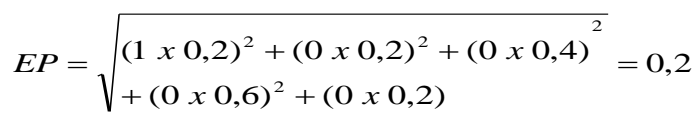

$\operatorname{Max}(0,74,0,4,0,4)=0,74$

Dari perhitungan yang telah dilakukan menggunakan Euclidean Probability, maka dapat disimpulkan bahwa pasien tersebut menderita penyakit Impetigo dengan nilai diagnosis 0,74 atau dengan persentase $74 \%$.

\section{Pengujian Metode}

Dalam menguji perbandingan metode antara Euclidean Probability dengan Teorema Bayes, akan menggunakan dua cara diantaranya adalah membandingkan nilai akurasi diagnosis dan membandingkan kedua metode menggunakan teknik eksponensial. Berikut ini adalah teknik pengujian perbandingan metode yang dilakukan:

1. Perbandingan nilai diagnosis

Berdasarkan hasil perhitungan yang dilakukan menggunakan Euclidean Probability dan Teorema Bayes maka diperoleh hasil diagnosis dengan jenis penyakit yang sama yaitu Impetigo dengan nilai diagnosis pada Euclidean Probability sebesar 0,74 atau dengan persentase $74 \%$ sedangkan pada Teorema Bayes menghasilkan nilai diagnosis sebesar 0,51 atau dengan persentase $51 \%$. engan hasil ini maka untuk kasus tersebut metode Euclidean Probability memiliki nilai diagnosis paling tinggi daripada Teorema Bayes dan dapat disimpulkan bahwa lebih baik daripada Teorema Bayes. Pengujian metode juga dilakukan dengan menggunakan beberapa data sampel kasus lainnya, hal ini dilakukan untuk menguatkan hasil dari akurasi diagnosis yang dihasilkan oleh Euclidean Probability dan Teorema Bayes. Berikut hasil diagnosis dari beberapa sampel kasus yang dapat terlihat pada Tabel 3 .

Tabel 3. Hasil akurasi diagnosis

\begin{tabular}{ccccccc}
\hline $\begin{array}{c}\mathrm{N} \\
\mathrm{o}\end{array}$ & Data Kasus & Eucli & Bayes & $\begin{array}{c}\text { Hasil } \\
\text { Metod } \\
\mathrm{e}\end{array}$ & $\begin{array}{c}\text { Hasil } \\
\text { Pakar }\end{array}$ & $\begin{array}{c}\text { Keses } \\
\text { uaian }\end{array}$ \\
\hline 1 & $\begin{array}{c}\text { G01, G02, } \\
\text { G03 }\end{array}$ & 0,74 & 0,51 & $\begin{array}{c}\text { Impeti } \\
\text { go }\end{array}$ & $\begin{array}{c}\text { Impeti } \\
\text { go }\end{array}$ & Ya (1) \\
2 & G10, G11 & 0,72 & 0,52 & $\begin{array}{c}\text { Frunk } \\
\text { el }\end{array}$ & $\begin{array}{c}\text { Frunk } \\
\text { el }\end{array}$ & Ya (1) \\
& $\begin{array}{c}\text { G04, G05, } \\
\text { G08 }\end{array}$ & 0,48 & 0,33 & $\begin{array}{c}\text { Impeti } \\
\text { go }\end{array}$ & $\begin{array}{c}\text { Impeti } \\
\text { go }\end{array}$ & Ya (1) \\
& $\begin{array}{c}\text { G01, G16, } \\
\text { G17 }\end{array}$ & 0,66 & 0,53 & $\begin{array}{c}\text { Lepro } \\
\text { sy }\end{array}$ & $\begin{array}{c}\text { Lepro } \\
\text { sy }\end{array}$ & Ya (1) \\
& $\begin{array}{c}\text { G11, G12, } \\
\text { G13 }\end{array}$ & 0,48 & 0,33 & $\begin{array}{c}\text { Frunk } \\
\text { el }\end{array}$ & $\begin{array}{c}\text { Frunk } \\
\text { el }\end{array}$ & Ya (1) \\
\hline
\end{tabular}

Berdasarkan data hasil diagnosis yang diperoleh dengan menggunakan 5 data sampel, maka diperoleh nilai validasi sebagai berikut : 
Validasi $\quad=\left(\sum\right.$ appro $/ \sum$ Data $) \times 100 \%$

$=(5 / 5) \times 100 \%$

$=100 \%$

Dari nilai akurasi yang telah dihitung, maka dapat dinyatakan bahwa Euclidean Probability dan Teorema Bayes memiliki nilai validasi $100 \%$, namun untuk perbandingan nilai diagnosis diketahui bahwa Euclidean Probability memiliki nilai diagnosis yang lebih tinggi daripada dengan Teorema Bayes.

Dengan hasil ini maka dapat disimpulkan bahwa Euclidean Probability lebih baik daripada Teorema Bayes dalam melakukan diagnosis terhadap penyakit Dermatic Bacterial.

2. Perbandingan metode menggunakan eksponensial

Tahapan teknik eksponensial diawal dengan menentukan nilai bobot dari alternatif yang ada pada Tabel 4 .

Tabel 4. Bobot eksponensial

\begin{tabular}{cc}
\hline Alternatif & Nilai Bobot \\
\hline Euclidean & 0,5 \\
Bayes & 0,5
\end{tabular}

Kemudian langkah selanjutnya adalah menghitung nilai prioritas masing-masing alternatif dari contoh sampel kasus dengan bobot eksponensial yang diberikan pada Tabel 5 .

Tabel 5. Hasil perhitungan

\begin{tabular}{cccccc}
\hline Alternatif & $\begin{array}{c}\text { Nilai } \\
\text { Diagnosis }\end{array}$ & $\begin{array}{c}\text { Nilai } \\
\text { Bobot }\end{array}$ & $\begin{array}{c}\text { Proses } \\
\text { Eksponen } \\
\text { sial }\end{array}$ & Hasil & Persentase \\
\hline Euclidean & 0,74 & 0,5 & $0,74^{0,5}$ & 0,86 & $86 \%$ \\
Bayes & 0,51 & 0,5 & $0,51^{0,5}$ & 0,71 & $71 \%$ \\
\hline
\end{tabular}

Berdasarkan perbandingan metode yang telah dilakukan menggunakan teknik perhitungan eksponensial, maka diperoleh hasil eksponensial pada Euclidean Probability dengan nilai prioritas 0,86 atau $86 \%$ dan Teorema Bayes mendapatkan nilai prioritas 0,71 atau $71 \%$. Dengan hasil ini maka dapat diketahui bahwa metode Euclidean Probability memiliki nilai prioritas lebih tinggi daripada Teorema Bayes. Berdasarkan fakta tersebut maka dapat disimpulkan bahwa Euclidean Probability lebih baik daripada Teorema Bayes dalam melakukan diagnosis terhadap penyakit Dermatic Bacterial.

3. Hasil Pengujian Metode

Dari hasil pengujian metode yang dilakukan untuk membandingkan Euclidean Probability dengan Teorema Bayes, maka diperoleh kesimpulan bahwa Euclidean Probability lebih baik daripada dengan Teorema Bayes. Berdasarkan perbandingan nilai diagnosis dan nilai prioritas dari teknik eksponensial, sehingga nantinya sistem yang akan dibangun akan menerapkan metode Euclidean Probability dalam menghasilkan nilai diagnosis terhadap penyakit Dermatic Bacterial.

\section{Implementasi Sistem}

Berdasarkan hasil pengujian metode yang telah dilakukan maka untuk implementasi sistem untuk mendiagnosa Dermatic
Bacterial akan menerapkan metode Euclidean Probability yang terpilih sebagai metode yang paling baik dibandingkan dengan Teorema Bayes. Pembangunan sistem ini akan menggunakan tools Microsoft Visual sebagai perangkat untuk merancang dan pengkodean dalam menghasilkan aplikasi layanan diagnosa Dermatic Bacterial.

Berikut merupakan tahapan dari penggunaan sistem yang telah dirancang. Didahului dengan tampilan halaman utama dari aplikasi layanan, dengan tampilan sebagai berikut :

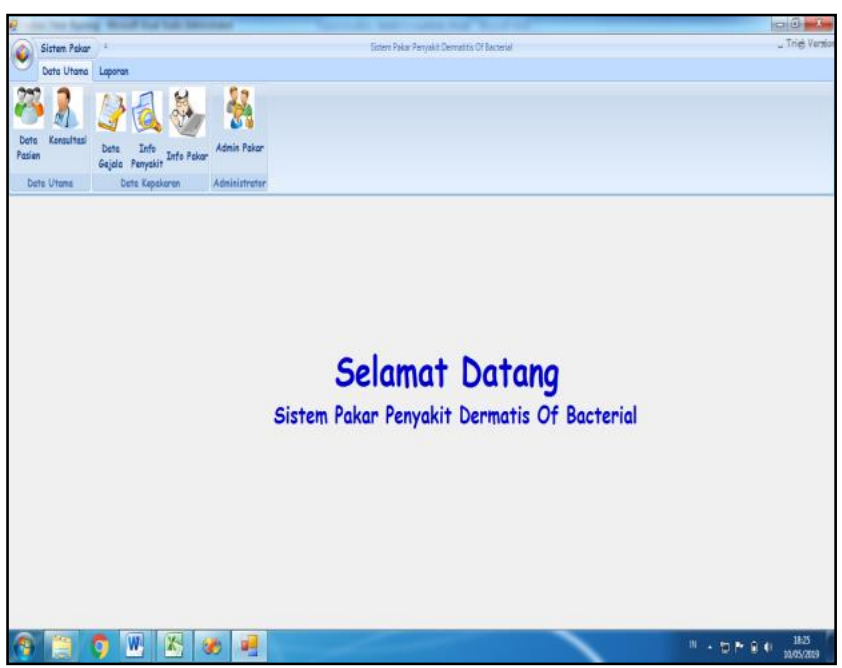

Gambar 1 Halaman utama

Halaman utama berisi tentang menu layanan yang disediakan untuk pengguna, selanjutnya mengisi data pasien pada menu yang telah disediakan, pengisian data pasien ini berfungsi untuk menyimpan data identitas diri dari seseorang yang melakukan diagnosa atau menggunakan aplikasi ini. Berikut merupakan hasil dari tampilan data pasien.

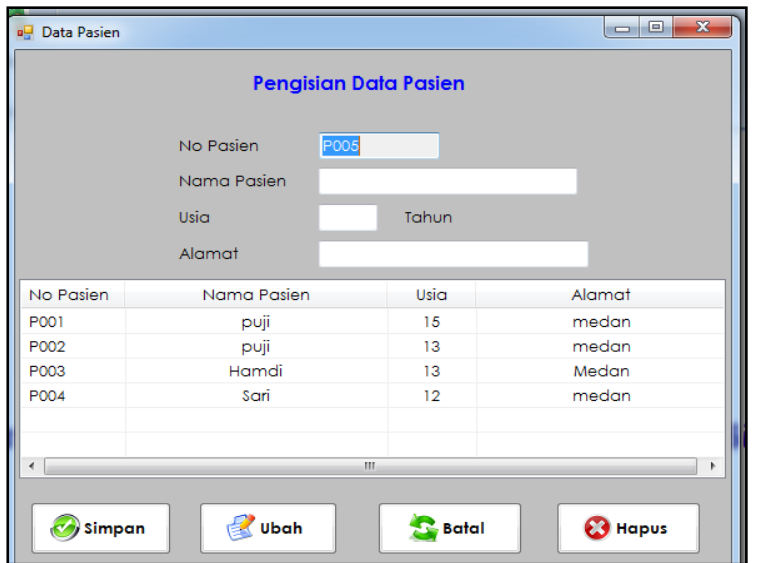

Gambar 2. Data Pasien

Form data pasien terdiri dari data identitas pasien yang nantinya dapat diubah, ditambahkan dan dihapus sesuai dengan keadaan dan kondisi mendatang, setelah mengisi data pasien maka selanjutnya adalah mengisi data gejala yang dialami pada form konsultasi diagnosa, berikut tampilan dari form konsultasi diagnosa : 


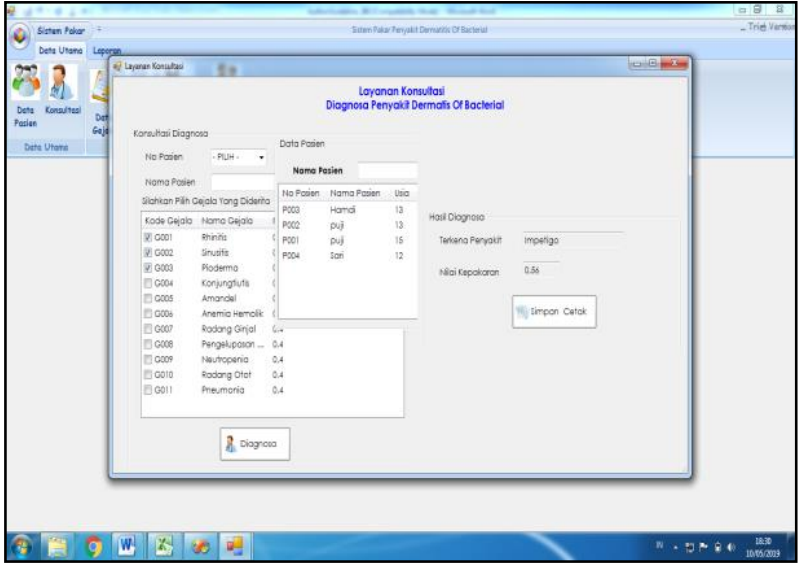

Gambar 3. Halaman Konsultasi

Setelah melakukan pengisian gejala nantinya sistem akan secara otomatis menampilkan hasil diagnosa berdasarkan gejala yang dipilih, maka untuk proses selanjutnya dapat menyimpan data diagnosa yang dapat digunakan sebagai bukti riwayat konsultasi.

\section{CONCLUSIONS}

Berdasarkan hasil penelitian yang telah dilakukan tentang perbandingan metode Euclidean Probability dengan Teorema Bayes dengan menggunakan perbandingan nilai diagnosis dan teknik eksponensial maka dapat diperoleh hasil perbandingan nilai diagnosis pada Euclidean Probability sebesar 0,74 atau 74\% sedangkan pada Teorema Bayes menghasilkan nilai diagnosis 0,51 atau $51 \%$ dengan sama-sama menghasilkan kesimpulan diagnosis yaitu jenis penyakit Impetigo. Kemudian untuk teknik eksponensial Euclidean Probability memperoleh nilai prioritas 0,86 atau $86 \%$ lebih besar dibanding Teorema Bayes yang mendapatkan nilai prioritas 0,71 atau $71 \%$. Dengan hasil perbandingan metode yang dilakukan maka dapat disimpulkan bahwa metode Euclidean Probability lebih baik daripada dengan Teorema Bayes dalam melakukan diagnosis terhadap penyakit Dermatic Bacterial.

\section{ACKNOWLEDGMENT}

Terima kasih Kepada Kemenristekdikti (Kementerian Riset, Teknologi dan Pendidikan Tinggi) dan DRPM (Direktorat Riset dan Pengabdian Masyarakat) yang telah memberikan bantuan pendanaan dalam publikasi ilmiah ini.

\section{REFERENCES}

[1] A. Maharani, Penyakit Kulit, 1st Ed. Yogyakarta: Pustaka Baru Press, 2015.

[2] P. S. Ramadhan, "Penerapan K-Nearest Neighbor Dalam Pendeteksian Abcessus," Vol. 2, 2019.

[3] E. D. Widianto, Y. W. Zaituun, And I. P. Windasari, "Khazanah Informatika Aplikasi Sistem Pakar Pendeteksi Penyakit Tuberkulosis Berbasis Android," Vol. 4, No. 1, Pp. 47-54, 2018.

[4] P. S. Ramadhan, Mengenal Metode Sistem Pakar, 1st Ed. Medan: Penerbit Uwais, 2018.

[5] Tuslaela And D. Permadi, "Sistem Pakar Diagnosa Penyakit Gigi Dan Mulut Berbasis Web Dengan Metode Forward Chaining," J. Prosisko, Vol. 5, No. 1, Pp. 17-26, 2018.
[6] A. Joshi And M. Ashish, "Analysis Of K-Nearest Neighbor Technique For Breast Cancer Disease Classification," Int. J. Recent Sci. Res., Vol. 8, No. 8, Pp. 1005-19008, 2017.

[7] M. El Agha, A. Jarghon, And S. S. A. Naser, "Polymyalgia Rheumatic Expert System," No. August, 2017.

[8] S. Qwaider And S. S. A. Naser, "Expert System For Diagnosing Ankle Diseases," No. August, 2017.

[9] E. Technology, D. Ayu, P. Wulandari, K. Ary, B. Permana, And M. Sudarma, "Prediction Of Days In Hospital Dengue Fever Patients Using K-Nearest Neighbor," Vol. 3, No. 1, Pp. 23-25, 2018.

[10] P. S. Ramadhan, "Penerapan Euclidean Probability Dalam Pendeteksian Penyakit Impetigo," Vol. 4, No. 1, Pp. 11-16, 2019.

[11] P. S. Ramadhan, "Sistem E-Diagnosis Untuk Pendiagnosaan X-Linked Agammaglobulineamia Menggunakan Euclidean Probability," Pp. 464-468, 2019.

[12] S. Nurajizah And M. Saputra, "Sistem Pakar Berbasis Android Untuk Diagnosa Penyakit Kulit Kucing Dengan Metode Forward Chaining," J. Pilar Nusa Mandiri, Vol. 14, No. 1, Pp. 7-14, 2018.

[13] P. S. Ramadhan, "Sistem Pakar Pendiagnosaan Dermatitis Imun Menggunakan Teorema Bayes," Infotekjar(Jurnanl Nas. Inform. Dan Teknol. Jaringan), Vol. 3, No. 73, Pp. 43-48, 2018.

[14] P. S. Ramadhan, "Sistem E-Pediatric Untuk Pendiagnosaan Eflorsen Dermatis Menggunakan Teorema Bayes," J. Sebatik, Vol. 23, No. 1, Pp. 242247, 2019.

[15] P. S. Ramadhan, "Sistem Pakar Pendeteksian Varicella Simplex Dengan Menggunakan Teorema Bayes," Vol. 5, No. 5, Pp. 454-459, 2018.

[16] P. S. Ramadhan, "Aplikasi Diagnosa Granulomatous Dermatis Menggunakan Certainty Factor," Vol. 3, No. 2, Pp. 78-83, 2019.

[17] P. S. Ramadhan And Fatimah, "Sistem E-Healthcare Untuk Mendiagnosa Penyakit Inflamasi Dermatitis Imun Anak Dengan Menggunakan Metode Certainty Factor," Vol. 1, No. 1, Pp. 251-256, 2018.

[18] S. A. Putri And E. P. Saputra, "Perancangan Aplikasi Sistem Pakar Diagnosa Awal Kanker Reproduksi Wanita Dengan Metode Certainty Factor," Vol. 2, No. 3, Pp. 63-68, 2018.

[19] A. Suyatno And D. M. Khairina, "Pendeteksi Gangguan Jaringan Lokal Menggunakan Metode Certainty Factor," Vol. 13, No. 2, Pp. 60-64, 2018.

[20] B. Sinaga, P. M. Hasugian, And A. M. Manurung, "Sistem Pakar Mendiagnosa Kerusakansmartphone," Vol. 3, No. 1, 2018.

[21] A. Al-Ajlan, "The Comparison Between Forward And Backward Chaining," Int. J. Mach. Learn. Comput., Vol. 5, No. 2, Pp. 106-113, 2015.

[22] U. Hanifah, F. T. Elektro, U. Telkom, A. V. Jones, And F. Chaining, "Deteksi Penyakit Pterigium Menggunakan Forward Chaining Dan Algoritma Viola Jones Detection Of Pterigium Disease Using Forward Chaining And Viola," Vol. 5, No. 3, Pp. 6118-6125, 2018.

[23] B. F. Yanto, I. Werdiningsih, And E. Purwanti, "Aplikasi Sistem Pakar Diagnosa Penyakit Pada Anak Bawah Lima Tahun Menggunakan Metode Forward Chaining," J. Inf. Syst. Eng. Bus. Intell., Vol. 3, No. 1, Pp. 61-67, 2017.

[24] A. Widjaja And A. B. Susilo, "Expert System To Identify Damage Cisco As5300 Device With The Method Of Forward Chaining-Based Client-," Vol. 9, Pp. 787-805, 2017. 
[25] J. Sistemasi Et Al., "Siti, Sistem Pakar Diagnosa Penyakit Pada Tanaman Kakao Menggunakan Metode Forward Chaining (Studi Kasus Dinas Perkebunan Indragiri Hilir) 1," Vol. 4, Pp. 1-8, 2015.

\section{NOMENCLATURE}

$P\left(H_{i} \mid E\right) \quad$ meaning probabilitas hipotesis $i$ terjadi jika evidence terjadi

$P\left(E \cap H_{i}\right) \quad$ meaning probabilitas evidence mengandung hipotesis, dan $P(E)$ adalah total probabilitas evidence

$E P$ meaning hasil Euclidean Probability, $E$ adalah nilai kondisi pada evidence, dan $N B E$ adalah nilai bobot evidence

\section{AUTHOR(S) BIOGRAPHY}

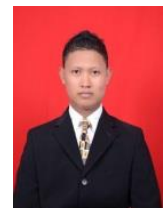

Puji Sari Ramadhan

Dosen Tetap STMIK Triguna Dharma, mengampu mata kuliah yang berkaitan dengan ilmu komputer. 